\title{
Iowa's Last Lynching: The Charles City Mob of 1907 and Iowa Progressivism
}

\author{
Michael JaMes Pfeifer
}

ON JANUARY 9, 1907, a mob of several hundred men, some masked with handkerchiefs and others undisguised, rammed down the doors of the Floyd County Jail in Charles City, Iowa, with a rail iron. Sheriff William Schermerhorn and several deputies offered only feeble resistance as the mob seized one of the prisoners, James Cullen. A wealthy, white, sixty-two-yearold contractor, Cullen had murdered his wife and stepson the previous day. As the mob hauled Cullen to a bridge over the Cedar River, Frank Roper, a Salvation Army officer, interceded to say a prayer for Cullen over the vehement protests of some of the less patient members of the mob. Cullen, at Roper's insistence, offered a prayer of his own and then reiterated that he had acted in self-defense. Rejecting a suggestion from some of the lynchers who wished to fill Cullen's body with bullets, one of the ringleaders insisted that a simple hanging would suffice. Approximately five hundred residents of Charles City, including women and children, witnessed Cullen's hanging from the Main Street bridge at 11:30 p.m. Then the mob quickly departed, leaving Cullen's lifeless body as a solitary reminder of the traumatic events of the previous 48 hours. $^{1}$

I would like to thank Shel Stromquist, Marvin Bergman, Bill Thomas, and several anonymous readers for their assistance.

1. Waterloo Times-Tribune, 10 January 1907; Des Moines Register and Leader, 10 January 1907; Floyd County Advocate, 11 January 1907.

THE ANNALS OF IOWA 53 (Fall 1994). CThe State Historical Society of Iowa, 1994. 
The lynching of James Cullen was the last mob killing in Iowa. Vigilantism has long been associated with frontier areas, and frontier Iowa was no exception to the pattern. ${ }^{2}$ Several lynchings also occurred as the state emerged from frontier conditions in the $1890 \mathrm{s.}^{3}$ Nonetheless, the hanging of James Cullen in 1907 struck many contemporary observers as an anachronism. Charles City, a community in the heart of the "civilized" North, had voted overwhelmingly for Albert B. Cummins and the progressive wing of the Republican Party in three successive gubernatorial elections in the first decade of the twentieth century. ${ }^{4}$ The town continued to back progressive Republicans in the years that followed Cullen's hanging. Residents of Charles City strongly backed Cummins's progressive agenda and were receptive to his message pitting "the people"

2. See Paul Walton Black, "Lynchings in Iowa," Iowa Journal of History and Politics 10 (1912), 151-254; and idem, "Attempted Lynchings in Iowa," Annals of Iowa 11 (1914), 260-85. For the historical characteristics of American vigilantism, see Richard Maxwell Brown, "Vigilantism in America," in H. John Rosenbaum and Peter C. Sederberg, eds., Vigilante Politics (Philadelphia, 1976), 102-4; Richard Maxwell Brown, ed., American Violence (Englewood Cliffs, NJ, 1970), 1-2; Richard Hofstadter and Michael Wallace, American Violence: $A$ Documentary History (New York, 1970), 11.

3. Lynchings reportedly occurred in Albia and Ottumwa in 1893, Missouri Valley and Iowa Falls in 1894, and Mitchellville in 1896. The Mitchellville incident involved an African American charged (by the mob) with assault; the others involved whites charged with rape, murder, or swindling. National Association for the Advancement of Colored People (NAACP), Thirty Years of Lynching in the United States 1889-1918 (1919; reprint, New York, 1969), 64.

4. Annual Register of the State of Iowa (Des Moines, 1901-1910). Charles City and Floyd County endorsed Cummins in Republican Party caucuses in 1901 and 1906 (delegates selected in 1903 refused to make commitments to particular candidates). See Floyd County Advocate, 9 July 1901, 23 June 1903, 20 April 1906. In June 1908 Iowa's first senatorial primary pitted Cummins against the elderly 'standpatter' William Boyd Allison, who received the energetic support of the state's railroad interests. On May 13 an enthusiastic, capacity crowd in Charles City heard Cummins deliver a campaign speech that included no mention of the Cullen lynching. Nonetheless, Allison outpolled Cummins by 171 votes in Floyd County and by only 18 votes, 320 to 302 , in Charles City. Allison also edged Cummins in the statewide tally, by a mere 10,635 votes. In November 1908, after Senator Allison's death, Cummins trounced another Republican primary challenger, J. F. Lacey, winning 65 percent of Charles City's vote and 59 percent of ballots statewide. Floyd County Advocate, 12, 15 May, 5 June 1908; Annual Register of the State of Iowa (Des Moines, 1910). 
against the nation's large financial interests. In this context a lynching required some explanation.

Residents of Charles City soon supplied one, as did the many Iowans from across the state who consoled the town in the midst of its ordeal. Expressing deep frustration with what they perceived as the failure of the existing legal system to enforce justice effectively, they posited the right of citizens who made the laws to enforce them if legal institutions failed to do so. Their defense of the Cullen hanging employed a definition of popular rights at odds with Cummins's understanding of the function of the criminal justice system and with the larger progressive agenda, which involved reforming laws and institutions. Nonetheless, the invocation of popular sovereignty by the defenders of Cullen's lynching was consistent with a broader understanding of "the people's rights" prevalent in political discourse in Iowa in the early twentieth century. For Charles Citians and their supporters statewide, an expansive conception of the popular role in the justice system meshed easily with the progressives' advocacy of more democratic political institutions. ${ }^{5}$

5. On Cummins and the Progressive movement, see Ralph Mills Sayre, "Albert B. Cummins and the Progressives in Iowa" (Ph.D. diss., Columbia University, 1958); Thomas James Bray, "The Cummins Leadership," Annals of Iowa 32 (1954), 241-75; George McDaniel, "Smith Wildman Brookhart" (Ph.D. diss., University of Iowa, 1985), 50-51; Leland Sage, A History of Iowa (Ames, 1974), 216-48. For other accounts of midwestern progressivism, see David P. Thelen, The New Citizenship: Origins of Progressivism in Wisconsin, 1885-1900 (Columbia, MO, 1972); idem, Robert M. La Follette and the Insurgent Spirit (Boston, 1976); Robert H. Wiebe, The Search For Order, 1877-1920 (New York, 1966); Russel B. Nye, Midwestern Progressive Politics: A Historical Study of Its Origins and Development, 1870-1958 (East Lansing, MI, 1959); E. Daniel Potts, "The Progressive Profile in Iowa," MidAmerica 47 (1965), 257-68. For midwestern populism and its relation to Republican Party factionalism in Iowa, see Jeffrey Ostler, Prairie Populism: The Fate of Agrarian Radicalism in Kansas, Nebraska, and Iowa, 1880-1892 (Lawrence, KS, 1993). For some time, historians have questioned the usefulness of the terms progressivism and progressive movement. See Peter G. Filene, "An Obituary for 'the Progressive Movement," American Quarterly 22 (1970), 20-34. Although it may be impossible to define exactly what "progressivism" was or its parameters as a historical phenomenon, I am using the term here merely to describe the political program and supporters of midwestern politicians such as Albert Cummins and Robert M. La Follette, as well as the historical period during which they enjoyed their greatest popularity (roughly 1900-1912). 
In the face of a mythology of the frontier West that tends to excuse, justify, or even glorify lynchings, western historians have rightly insisted recently that lynching is murder and must be condemned as such. ${ }^{6}$ But it is also important to understand that lynchers - even in the heart of the "civilized" North could often draw on widespread popular support based on a long American tradition and ideology of vigilantism. ${ }^{7}$ A close examination of the hanging of James Cullen, and of the rhetoric of Iowans who condoned the lynching, reveals that vigilantism, far from being an aberrant and ephemeral phenomenon, retained both deep roots and considerable contemporary relevance for small-town Iowans in the early twentieth century.

AT THE TURN OF THE CENTURY the north central Iowa town of Charles City had a population of less than five thousand, with an economy centered around the manufacturing of farm

6. See, for example, Frank E. Vyzralek, "Murder in Masquerade: A Commentary on Lynching and Mob Violence in North Dakota's Past, 1882-1931," North Dakota History 57 (1990), 20-29.

7. Compare Michael J. Pfeifer, "The Ritual of Lynching: Extralegal Justice in Missouri, 1890-1942," Gateway Heritage (Winter 1993), 22-33. Although defenders of the Charles City lynching identified with Progressive Era values and consciously distinguished themselves from contemporary southern lynchers, they also placed themselves in a national tradition of vigilantism, thus linking themselves with southern mobs and Iowa vigilantes of the past. A Waterloo editorialist asserted that the sectional discrepancy in the rate of lynchings resulted merely from the difference in "local race conditions." Region is irrelevant, the editorialist argued. "A man will protect his wife and daughter regardless of consequences. He always has done it." Waterloo TimesTribune, 12 January 1907.

8. David Johnson, "Vigilance and the Law: The Moral Authority of Popular Justice in the Far West," American Quarterly 33 (1981), 558-86, has argued that lynching lost popular sanction in California by the latter third of the nineteenth century. However, the evidence presented here for Charles City, and even Vyzralek's evidence for North Dakota, suggests that vigilantism retained substantial popular support into the early twentieth century in the states of the upper Midwest. For an 1889 Wisconsin lynching with interesting ethnic and gender dimensions, see Jane M. Pederson, "Gender, Justice, and a Wisconsin Lynching, 1889-1890," Agricultural History 67 (1993), 65-82. Western and midwestern historians interested in vigilantism stand to profit from the many perceptive studies of southern lynching published in recent years. The definitive study of southern lynching is W. Fitzhugh Brundage, Lynching in the New South: Georgia and Virginia, 1880-1930 (Urbana, IL, 1993). 
implements. James Cullen participated actively in the local economy, accumulating substantial personal wealth as a contractor making wooden tanks for homes and businesses. Born in Wisconsin in 1844 to parents who had emigrated from Ireland, Cullen became well-known during his approximately twenty-five years in the community for his support for temperance and for his temper. He had business and social contacts with prominent men in Charles City and throughout Iowa, including state legislators and other state officials. Twice married and divorced, Cullen, in July 1906, married Ellen Brown Eastman, a native of neighboring Chickasaw County who had previously operated a hotel in Fredericksburg. The Cullen household also included two boarders: Royal Jacobs, a student, and L. E. Reed, a professor at Charles City College. ${ }^{9}$

The Cullens soon quarreled over financial matters, with much of their argument apparently revolving around Ellen's son, fifteen-year-old Roy Eastman. Agitated over his dispute with his wife and stepson, Cullen wired his brother, Richard, a banker in Warren, Illinois, on Monday afternoon, January 7. Responding to his brother's telegram, Richard Cullen arrived in Charles City at 2:30 the next morning. He asked James why he had been summoned in such a strange manner (the second time in a month), but received no answer. Richard then went to a guest room and fell asleep. ${ }^{10}$

What happened next can be pieced together from the testimony of Richard Cullen and the two boarders, which was published in the local newspaper, the Floyd County Advocate, on January 11. Sometime before 4 a.m. - perhaps even before Richard's arrival-James Cullen attacked his wife in her bed and stabbed her to death with a large knife. Richard Cullen soon

9. Census of Iowa for 1905, 668; Floyd Co. Centennial Centurama, 1854-1958 (Charles City, 1957), 24-25; U.S. Census of Population, Manuscript Census, Town of Charles City, Floyd County, Iowa, 1900; Iowa Census of Population, Manuscript Census, Town of Charles City, Floyd County, 1885, 1895, 1905; Waterloo Times-Tribune, 11 January 1907; Floyd County Advocate, 11 January 1907; Des Moines Register and Leader, 11 January 1907.

10. Coroner's juries reports, 8, 10 January 1907, in Floyd County Advocate, 11 January 1907 (hereafter cited as coroner's reports); Des Moines Register and Leader, 9 January 1907. 
awoke to the sound of loud noise in another part of the house. Hurrying downstairs, he encountered Roy Eastman in a struggle with his stepfather, James Cullen, who was armed with a knife. Richard Cullen and the two boarders, Reed and Jacobs, managed to separate the two combatants and found that Eastman had been cut on the hand and neck, but that Cullen had not sustained any injuries in the altercation. After Eastman insisted that Cullen had surprised him in his sleep with the knife, Richard Cullen told Eastman that he would protect him from his stepfather. But then Eastman left Cullen's presence. Intending to go out to inform the marshal, the teenager went into the front hall, where James Cullen shot him twice with a pistol. Eastman died shortly afterwards. ${ }^{11}$

The distraught murderer told his brother that he was going to get the marshal, but instead went across the street to the house of Dr. F. E. Hirsch, the president of Charles City College. Cullen told Hirsch that he had murdered his wife and his stepson, but only after both had repeatedly threatened his life and tried to take his property away from him. Cullen returned to his house and unsuccessfully attempted to commit suicide; the bullet intended for his own head glanced off his skull, inflicting only scalp wounds. Again, he returned to Hirsch's house, but Hirsch refused to speak with him. As Cullen walked into the downtown area, Sheriff William Schermerhorn and Marshal Will Braend, whom Hirsch had telephoned, arrested Cullen and took him to the county jail. ${ }^{12}$

A feverish mood gripped Charles City as news of Cullen's crime swept the town on Tuesday, January 8. Gathering outside the county jail that evening, a small but noisy crowd shouted slogans expressing outrage at Cullen's crime and suggesting that he should be hanged for his offense. But after hanging Cullen in effigy, the mob dispersed, doing no further damage. ${ }^{13}$

The next day, rumors abounded in Charles City and the surrounding countryside that there would be an attempt to lynch Cullen that night. A Charles City restaurant owner,

11. Coroner's reports; Des Moines Register and Leader, 9 January 1907.

12. Coroner's reports; Des Moines Register and Leader, 9 January 1907.

13. Des Moines Register and Leader, 10 January 1907; coroner's reports. 
Liberty Martin, later testified that "there was a large crowd in our place of business, not many strangers, if any, were among them. I overheard some talk of hanging Cullen, but nothing definite." By early evening, the mayor, marshal, and sheriff were well aware that an attempt at a lynching was likely. ${ }^{14}$

Not surprisingly, contemporary observers differed in the details of their descriptions of the mob that lynched James Cullen late in the evening of January 9. They agreed that the mob was "orderly" and that the lynchers acted according to a prearranged plan that was carried out with the "precision of an army movement." Some reports, however, also characterized the mob as "frenzied" and "howling and yelling." The Charles City mob behaved in a manner that was both "cool and relentless," for the lynchers and the crowd that watched them were determined that Cullen would hang for his offense. ${ }^{15}$

It appears that the mob that gathered at the lynching represented a broad spectrum of Charles City's population. Reports of the size of the mob varied from 250 to 1,000 persons, with several observers agreeing that there were about 500 persons present, more than 10 percent of the town's population. The composition of the mob was apparently quite diverse. A. M. Treynor, a Des Moines reporter, wrote that "James Cullen was pulled aloft, while businessmen, women, and children stood by and did not interfere. . . . It was justice dealt out, almost as a community and with the approval of all that was best in the town." One newspaper report, widely circulated by wire services, suggested that four or five ministers participated in the lynching, causing several churchmen later to sign a sworn statement denying their attendance. Others noticeably absent from the diversity represented in the Charles City mob were the elite residents of the town. The wealthiest Charles Citians were apparently isolated in their opposition to the lynching. ${ }^{16}$

The Charles City mob consisted of two separate groups: active participants, many of them young men, and a large het-

\section{Coroner's reports.}

15. Des Moines Register and Leader, 10 January 1907; Waterloo Times-Tribune, 10 January 1907; coroner's reports.

16. Coroner's reports; Des Moines Register and Leader, 10, 13 January 1907; Waterloo Times-Tribune, 10, 11 January 1907. 
erogeneous crowd that avidly watched the aggressive lynchers drag Cullen through the streets and hang him from the bridge over the Cedar River. Salvation Army officer Frank Roper told a Waterloo newspaper that most of the mob's members were under thirty years of age. Roper and other observers described the most prominent ringleader, who gave commands and directed the vigilantes, as a tall young man with a distinctive voice. The large, mixed crowd that observed the lynching offered shouts of encouragement. Roper also stated in the newspaper interview that "a few women lingered in the outskirts of the mob at the jail and followed the throng when it had secured Cullen to his place of execution." Treynor asserted that "business" class wives and children remained at home as their husbands and fathers joined the active vigilantes and the crowd in what they perceived as a defense of the sanctity of the home and the familial relations it encompassed in Charles City. ${ }^{17}$

The mob's narrowly defined purpose - the death of Cullen - prevented participants from indulging in the sadomasochistic excess familiar to southern lynchers by the early twentieth century. When some mob participants proposed to riddle Cullen's body with bullets, the young man identified as the most prominent of the ringleaders successfully objected, "Hanging goes tonight, but not murder!" After Cullen expired, the mob quickly left the scene. No one retrieved the "gruesome keepsakes" souvenirs of clothing and body parts - with which southern mobs often satisfied communal vengeance. The point had been made: Cullen's death by hanging sufficed for Charles Citians as a communal punishment for his crime. The simplicity of Cullen's lynching may reflect the difference between the tradition of vigilantism in Iowa and the dynamic, repressive meaning lynchings took on in southern communities dealing with questions of racial order at the turn of the century. ${ }^{18}$

17. Waterloo Times-Tribune, 10, 11 January 1907; coroner's reports; Des Moines Register and Leader, 10 January 1907.

18. Des Moines Register and Leader, 10, 11, 12 January 1907; Waterloo TimesTribune, 10, 11 January 1907; coroner's reports. For "gruesome keepsakes," quasiliturgical aspects of lynchings, and lynching as a means to reassert racial hegemony in a rapidly changing social order, see Pfeifer, "Ritual of Lynching"; Brundage, Lynching in the New South; Bertram Wyatt-Brown, Southern Honor 
The role of the community's law officers in bringing the vigilantes to justice, as well as in preventing their miscarriage of justice in the first place, was not so different, however. Despite persistent rumors of the impending lynching, Sheriff William Schermerhorn offered only token resistance, at best, to the vigilantes who stormed the jail he was sworn to protect. Assessing Schermerhorn's performance several days after the event, a Des Moines newspaperman wrote, "As to whether Schermerhorn was a hero or a coward largely depends upon the point of view. If discretion is the better part of heroism as well as valor, Schermerhorn is entitled to the honor. Otherwise - well, there is some doubt about it."19

Others were less equivocal about Schermerhorn's role. Judge C. H. Kelley, who oversaw a grand jury in session in Charles City when the Cullen lynching occurred, quickly empowered the grand jury to investigate Cullen's death. On January 8 Schermerhorn had sought the advice of Judge Kelley and the Floyd County Board of Supervisors, who told him that as the sheriff he must decide whether Cullen should be removed to another jail for safekeeping. Schermerhorn, who had taken office only two days earlier, later testified that "others" he consulted regarded the lynching rumors as "foolish and only a scare," so he decided to do nothing. After Cullen's death, Kelley rebuked Schermerhorn for failing to take a stand against the mob, neglecting even to draw his gun in resistance to the lynchers. $^{20}$

The sheriff later argued that he did not regard any of the talk of lynching seriously until it was almost under way. But the circumstances surrounding Cullen's abduction make a strong case for Schermerhorn's tacit cooperation with the mob. According to his testimony, four masked men ambushed him after he returned from the courthouse, where he had taken the jailhouse

(New York, 1982), 453-61; Neil R. McMillen, Dark Journey (Urbana, IL, 1989), 234-35; Joel Williamson, The Crucible of Race (New York, 1984), 185-89, 308-9, 314-15; David Thelen, Paths of Resistance (New York, 1986).

19. Des Moines Register and Leader, 12 January 1907.

20. Ibid., 10, 13 January 1907; Waterloo Times-Tribune, 10, 11 January 1907; Floyd County Advocate, 11, 15 January 1907. 
keys for safekeeping at approximately 10:15 p.m. on the night of the lynching. The masked men allegedly told him, "You are the lad we're looking for, you needn't be afraid, we are not going to hurt you, but we will have James Cullen tonight." Similarly, Marshal Will Braend testified that he was kidnapped by mob members and prevented from interfering with the lynchers. Braend and Schermerhorn also stated that they had attempted to deputize citizens as rumors of the impending lynching circulated. Their efforts, half-hearted and belated at best, amounted to little. Waiting out the mob in separate parts of the courthouse, where they were left unguarded, Braend and Schermerhorn listened to the mob proceed to the jail, ram down the door, and extricate Cullen. Nonetheless, both later testified that they were unable to identify any of the lynchers. ${ }^{21}$

Many Charles Citians approved of Schermerhorn's handling of the lynching. When Judge Kelley accused the sheriff of negligence, townspeople zealously defended him. Charles Citians also reaffirmed their support for Schermerhorn in a primary election in June 1908. In that contest Schermerhorn polled 320 votes, 81 more than the nearest of his three competitors. Schermerhorn's supporters in the 1908 primary charged that a prominent law firm was bankrolling one or more of Schermerhorn's opponents because the firm's members would have profited considerably from Cullen's prosecution. The editor of the Floyd County Advocate, a Schermerhorn partisan, castigated the county attorney, L. O. Rue, for publicly stating that Schermerhorn had been negligent in enforcing local liquor licensing. The editor also suggested that the county attorney made his allegations against Schermerhorn because the lynching had deprived Rue of the fame, and of the possibly lucrative political career, that would have inexorably followed his prosecution of the Cullen case. ${ }^{22}$

21. Des Moines Register and Leader, 10, 13 January 1907; Waterloo Times-Tribune, 10, 11 January 1907; Schermerhorn's and Braend's testimony in coroner's reports; Floyd County Advocate, 15 January 1907.

22. Floyd County Advocate, 15, 29 January 1907; 12, 19, 22, 26, 29 May, 2, 5, 9 June 1908. 
THE LYNCHING of James Cullen, while interesting in its own right, also reflected the strength of communal values within a changing society. ${ }^{23}$ The local press noted that James Cullen had long been notorious in the community for his unpredictable personality, particularly his volatile temper. Charles Citians asserted after the fact that the murder victims had been popular in the community, with long ties to the area because of their origins in neighboring Chickasaw County. Residents remembered that Cullen's previous marriages had been failures, that he had mistreated his former wives, and that no one in Charles City could understand Ellen Eastman's reasons for marrying Cullen the previous year. In the realm of local opinion, which emphasized the importance of relations within the family for the sustenance of communal ideals, Cullen's murder of his wife and stepson marked him as a scoundrel, a menace to the community and its values. The community's resort to extralegal measures to remove that menace indicated its temporary rejection of modern legal institutions. ${ }^{24}$

The timing of the local events - their relation to another sequence of events in a nearby community - contributed to the hysterical wave of indignation and fear that gripped Charles City in the second week of January. Just three days before the double murder, on Friday, January 4, Governor Albert Cummins had commuted the sentence of Louis Busse from death to life imprisonment. In June 1901 Busse had murdered his wife in neighboring Butler County. Although an enraged local populace "whispered" threats of mob action after his arrest, Busse never faced a lynch party. Local press reports following Cullen's hanging noted that Charles City residents had carefully followed the progress of Busse's murder case through the courts. Some Charles Citians, noting the substantial funds Busse's family was

23. For scholarly treatments of the dynamics of mob behavior, see George Rude, The Crowd in History, 1730-1848 (New York, 1964); E. J. Hobsbawm, Primitive Rebels (Manchester, U.K., 1959); E. P. Thompson, "'Rough Music': Le Charivari Anglais," Annales; Economics; Societies; Civilization 27 (1972) 285-312; Rosenbaum and Sederberg, eds., Vigilante Politics; Clark McPhail, The Myth of the Madding Crowd (New York, 1991); Pfeifer, "Ritual of Lynching." 24. Waterloo Times-Tribune, 11 January 1907; coroner's reports; Des Moines Register and Leader, 12 January 1907. 
able to apply to his case, expressed frustration with his lawyer's success in the state appeals process. In five instances, judges had set execution dates for Busse, with reprieves granted on each occasion. The state supreme court had twice reviewed his conviction. The court rejected an argument for a writ of habeas corpus filed by Busse's attorney, but divided evenly on whether Busse should receive a second trial on the murder charge, thus affirming the death sentence. ${ }^{25}$

After the supreme court split on whether the murder conviction should be overturned, five supreme court justices wrote to Governor Cummins asking that he commute Busse's sentence to life imprisonment. The justices argued that it would set a bad precedent for the state to execute someone when half of the justices thought that he had not received a fair trial. Cummins responded to the justices' logic in a statement that accompanied his commutation order. Acknowledging that "a more cruel, brutal, and atrocious crime was never committed than the one of which Louis Busse is guilty," he nonetheless concluded,

A fair trial is one of the rights guaranteed to every person accused of a crime, whether he be high or low, rich or poor, and without regard to the character of the crime charged against him. In the case before me, I cannot doubt that the second trial would have resulted in a conviction of murder in the first degree; but I cannot assert that the penalty affixed would have been death.

In view, therefore, of the fact that one-half of the members of the supreme court held that Louis Busse did not receive a fair trial, coupled with the recommendations that are now before me, I have reached the conclusion that it is my duty to commute the sentence into a sentence of imprisonment for life. ${ }^{26}$

The regional press claimed that residents of northern Iowa viewed the commutation of Busse's death sentence as part of a disturbing pattern. Northern Iowans linked the Busse incident to a series of disappointments with the state legal system's punishment of serious violators of community norms. Nine of the twelve men sentenced to death in Iowa since 1894 had es-

25. Floyd County Advocate, 2, 5 July, 27, 30 August 1901; Des Moines Register and Leader, 4, 5 January 1907; Floyd County Advocate, 15 January 1907.

26. Des Moines Register and Leader, 4, 5 January 1907. 
caped the gallows through new trials, more lenient sentences, or pardons. Northern Iowa's recent history made the situation even more troubling to some concerned citizens. As a writer in the Floyd County Advocate explained, the most significant factor in the lynching was "the fear that by the aid of his money and able legal counsel Cullen would have been able to have escaped the gallows and perhaps the penitentiary, and would have later been released as was the case with McWilliams the Buchanan county murderer [who had murdered his wife and five children a year earlier], and the Professor at Decorah who murdered his neighbor with a spade and was afterward declared insane and later sent to the asylum and soon discharged as cured." 27

James Cullen's double murder provoked new fears: Cullen had an estate reputedly valued at fifty thousand dollars; he had contacted a lawyer the day after killing his wife and stepson; and he might make a credible case, based on his erratic personality, for his insanity. ${ }^{28}$ At the lynching the crowd shouted slogans that demonstrated their understanding of the significance of the communal murder of Cullen. Observers and listeners reported hearing, "There'll be no Louis Busse justice in this." The mob's lexicon also included numerous references to "McWilliams" and "the Decorah Professor" - the convicted murderers from nearby communities who had gained their release-expressions regarding the nature of Cullen's crime and the necessity of protecting Charles City families, and the threat to use dynamite if necessary to obtain the mob's objective. ${ }^{29}$ In recent serious criminal cases, Iowa's formal legal institutions had failed to assuage communal demands for justice, that is, for the execution of murderers. James Cullen's lynching reflected Charles Citians' resolution that his case would end differently.

ALTHOUGH A MINORITY of the town's population actively participated in or observed Cullen's hanging, very few citizens spoke out in opposition to the mob's action. The small group

27. Ibid., 4 January 1907; Floyd County Advocate, 11 January 1907.

28. Floyd County Advocate, 11 January 1907.

29. Des Moines Register and Leader, 10, 11, 12 January 1907; Waterloo Times-

Tribune, 10, 11 January 1907; Floyd County Advocate, 11 January 1907. 
of townspeople who did publicly declare their opposition to Cullen's lynching included several prominent ministers who composed the "ministerial alliance" and a few other elite professional men, such as the physician, William Seymour, and the president of Charles City College, F. E. Hirsch. ${ }^{30}$

After the lynching, the ministerial alliance organized a public meeting on January 14 to voice opposition to the mob's action. At that meeting, attended by six hundred people, the Charles City elite's position was expressed most succinctly by a Methodist minister, the Reverend Nathaniel Pye.

A city of churches of courts of schools and factories has given way to the methods of primitive and half civilized life.... When that mob (many of them under the influence of liquor) gathered in front of the jail and forced that railway iron through its door they did more! they drove it through the purity, the fidelity and the heroism of the Stars and Stripes and tore it to tatters. For over every jail, confining prisoners of every degree throughout our fair land, floats the invisible and indissoluble flag of our nation sheltering the poor wretch within until he shall have had a fair trial by his peers and have been proven guilty. ... Are we going to give this our consent? Are we afraid to condemn this awful crime against our rights and liberties? ... It is not that I care so much for Cullen, except that in him potentially is wrapped all that protects me and mine in life, character and property. Cullen was too vile and wretched to make it worth while for hundreds of upright citizens to stain their hands with the scarlet of human blood. ${ }^{31}$

Judge Kelley agreed. "The crime with which James Cullen was accused," he told the grand jury he convened to bring charges against the vigilantes, "pales into insignificance when compared with the deliberate act of an organized mob. . . . [Cullen] was murdered, gentlemen, and every person who actively participated in the act, or who aided and abetted it, is equally guilty of murder." For elite Charles Citians, the supremacy of established law and the guarantee of a fair trial took precedence over the heinous nature of Cullen's crime and the

30. Des Moines Register and Leader, 10, 11, 12 January 1907; Waterloo TimesTribune, 10 January 1907; Floyd County Advocate, 11, 15, 18, 22, 25 January 1907. 31. Floyd County Advocate, 15 January 1907. 
unlikelihood of swift punishment for his violation of community norms. ${ }^{32}$

Few other residents of Charles City expressed disapproval of the lynching. The grand jury that was convened at Judge Kelley's instruction eventually abandoned its investigation of the lynching because witnesses were unwilling to name mob members. The code of silence did not extend to expressions of support for the lynchers, however: townspeople did not hesitate to voice their approval of the vigilantes to local and visiting newspapermen. They were joined in their defense of the lynching by a number of small-town editorialists from around Iowa. Together, they formulated an impassioned critique of the prevailing legal system, and an argument for the efficacy of vigilantism in remedying the legal system's defects. Their critique centered around, in the words of a Charles City opinion writer, the failure of the law to protect the public in its pursuit of "life, liberty, and the pursuit of happiness," or, in other words, the traditional American ideology of republicanism, as codified in the Declaration of Independence. ${ }^{33}$

As a peripheral, but significant issue, defenders of the mob repeatedly took issue with Rev. Pye's claim that the lynching had been performed by men under the influence of strong drink. They argued that members of the Charles City mob had been completely sober and that Cullen's reputation as a temperance "crank" showed that not all evil could be attributed to the curse of liquor. The frequency with which this argument appeared in the press signals the importance of the liquor issue to Charles Citians. There is no clear correlation between Charles City residents' feelings about temperance and their feelings about the lynching, but it is clear that their depth of feeling about both led them to combine the issues rhetorically. ${ }^{34}$

32. Ibid., 11, 15, 25 January 1907.

33. Ibid., 15 January 1907.

34. Ibid., 8 February, 11, 15 January 1907, 12, 19, 22, 26, 29 May, 2, 5, 9 June 1908. For late nineteenth- and early twentieth-century agitation for and against the regulation of the purchase and consumption of alcohol, see Norman $\mathrm{H}$. Clark, Deliver Us from Evil (New York, 1976), and Perry Duis, The Saloon (New York, 1983). For Iowa, see Dan Elbert Clark, "The History of Liquor Legislation in Iowa, 1878-1908," Iowa Journal of History and Politics 6 (1908), 503-35. In 
H. Durkee, in a letter to the local newspaper, addressed the liquor issue and, more importantly, summarized the ideology of vigilantism Charles Citians' employed in Cullen's hanging.

There are some few (and I think a mighty small few), in this town who condemn the mob that lynched Cullen, but have no word of censure for the judges of our courts who manage through technicalities of the law to furnish a loophole through which most of the criminals escape. Now, it's a fair question to ask who is the most guilty of breaking the law - the mob or the officers who are sworn to unhold [sic] and execute the law? ... The mob enforced the law, done it up cheaply, scientifically, and with religious rites. Moreover, Cullen was buried with distinguished honors, having for pallbearers the elite of the town. ... Our people were under a tremendous mental strain. Never in the history of Charles City have her people... f felt the necessity of meting out justice swiftly and surely to a monster of inhumanity. That it was done without aid of whisky or mutilation of the body speaks well for our citizens, who are now and always have been law-abiding and peaceful citizens. The law has been vindicated; what more is wanted? The people make the law [;] the people can suspend the rules and hurry up justice when occasion requires it. Property in Charles City is worth 20 per cent more since the majesty of the law has been vindicated. No Bengal tiger can roam our streets when we have a sturdy manhood to shoot or hang to death any fiend, be he man or beast. ${ }^{35}$

Floyd County in 1905, 60 percent of church members $(2,145)$ were members of "pietistic" denominations (in order of numerical strength, the Methodist, Congregationalist, Christian, and Regular Baptist churches), while 38 percent $(1,345)$ were members of "liturgical" denominations (Lutheran and Catholic churches). According to Richard Jensen, The Winning of the Midwest: Social and Political Conflict, 1888-1896 (Chicago, 1971), "pietists" tended to take a stronger line against alcohol than "liturgicals." The 1905 state census also characterized 15 per cent of Charles City's population, and 13 percent of Floyd County's population, as foreign-born, with 52 percent of Floyd County's immigrant population being Germans, who tended to imbibe more alcohol than other ethnic groups. Census of Iowa for 1905, 877, 686, 518, xxxiv. A reading of the Charles City press in the early years of the twentieth century reveals a persistent political conflict between temperance advocates and those who took a softer line on liquor, although the composition of those factions apparently shifted over time, which make it dangerous to posit definite connections among positions on temperance, the Cullen lynching, and the town's political alliances.

35. Ibid., 8 February 1907. 
Durkee and other defenders of the lynching thus invoked the people's basic right to make and supervise the law, and to correct its supposed defects. Durkee referred to the psychological strain experienced by the Charles City community in reaction to Cullen's crime, the cathartic effect of the lynching, the masculine ideology of the lynchers who hanged Cullen to protect their wives and children, and the class division between elite Charles Citians and the rest of the town over the lynching.

A minister at the First Baptist Church in Iowa Falls, the Reverend J. R. Hargreaves, employed the vigilante ideology in a sermon expressing support for the Charles City mob. Invoking popular sovereignty, Hargreaves declared vigilantism a valid remedy for the defects of Iowa's legal system.

The people after all are the law makers and enforcers while jurists and other court officials are but delegated authorities. If those to whom the work is delegated are repeatedly remiss in duty, it might seem as though the original power must at times take matters in hand.

In the recent lynching, the fault is not so much with the Charles City mob as that condition in legal affairs which could permit a trial [Louis Busse's] for one of the most atrocious murders ever committed in the state to drag over several years in its various stages and appeals. ... The murdering of women and children at the hands of degenerate men has become so common in our fair state that the people have reason to become desperate when, with pretty good reason, they have reason to fear further miscarriage of justice. ...

Mobs are sometimes necessary to offset mobs. Many people make fat livings by delivering other people from their just deserts. Take away that mob, which, for a fee, will protect people to the very gate of the penitentiary and prevent the same opening to receive them, and there will be less unrest on the part of the masses. ${ }^{36}$

Editorialists from around Iowa added their own explanations and defenses of Cullen's hanging, and their views were reprinted by the dozens in the local newspaper, the Floyd County Advocate. Most commentators began with a blanket condemna- 
tion of lynchings in principle as a "bad business," then devoted most of their attention to the "but" that inevitably followed. They suggested that a general disgust with the inefficiency of the legal system, and especially with the machinations of lawyers, prevailed throughout the state. Small-town editorialists readily admitted that a similar set of circumstances might have provoked a lynching in their communities. They also argued that some good might come from the unfortunate Cullen case, if it would prod the governor, the legislature, and the courts to reform the legal system. They asserted that the legal system must be recast so that wealthy criminals could no longer get off through manipulation of the legal mechanisms designed to protect the rights of those charged with serious crimes. ${ }^{37}$

In particular, supporters of the Cullen hanging, who valued an effectively enforced death penalty as a deterrent to heinous criminals, argued that a state death penalty was useless if not rigorously enforced by state officials. They suggested that its rigid application would dramatically cut the murder rate. Discussions of state-sponsored executions took place in the context of a long debate over the death penalty in Iowa. The state legislature had abolished capital punishment in 1872, only to restore it in 1878 after a rancorous public debate in which proponents of restoration pointed to several recent lynchings and a series of well-publicized homicides. Nonetheless, humanitarian sentiment against the death penalty retained strength in religious and political circles. Early in the legislative session that began in January 1907, opponents of the death penalty reintroduced legislation to abolish capital punishment. Editorial supporters of the Cullen lynching characterized the timing of that legislation as inappropriate at best, and the legislation went nowhere in that session. ${ }^{38}$

37. Floyd County Advocate, 15, 18, 22, 29 January, 1, 5, 8, 12 February 1907.

38. Floyd County Advocate, 15 January, 1 February 1907; "Restoration of Capital Punishment," Annals of Iowa 35 (1959), 69-72; Richard Acton, "The Magic of Undiscouraged Effort: The Death Penalty in Early Iowa, 1838-1878," Annals of Iowa 50 (1991), 721-50. Contention over the death penalty in Iowa lasted at least until the early 1960s, when the state abolished capital punishment, although disputation of the issue continued even through 1994. 
DEFENDERS of the Charles City mob targeted Governor Albert Cummins directly. Many small-town editorialists attacked Cummins's specific actions in the Busse case, and argued that the governor's pardoning power ought to be restricted. Critics contended that the unwillingness of the governor and the supreme court to enforce the death penalty encouraged violent criminals and sapped the confidence of the public in the established law. A Cedar Rapids newspaper writer chided Cummins for his "misplaced mercy"; and a letter writer in a Charles City newspaper mocked the "maudlin sentiment of the Supreme Court and the chickenheartedness of an otherwise brilliant governor." Editorialists directed most of their fire at the supreme court and at the chicanery of skilled lawyers, leavening their derision for Governor Cummins's actions in the Busse case with praise for the rest of his record. Even the Creston Advertiser, a longtime political opponent of Cummins, admitted that, in all fairness, Cummins was harder on criminals than his predecessors, who had abused the pardoning power much more flagrantly. ${ }^{39}$

For his part, Governor Cummins quickly condemned the Charles City lynching, stating that he could not "adequately express his horror" at Cullen's hanging. After it became obvious that the grand jury in Charles City would not easily obtain positive identification of the lynchers, Cummins offered a reward of five hundred dollars for information leading to the arrest and conviction of any of the participants in the Charles City mob, but the reward failed to induce witnesses to come forward and name names. Several newspapers, including the Waterloo Times-Tribune, supported the governor's actions in response to the lynching and criticized the laxity of Charles City's law officers; and a Marshalltown lawyer, J. H. Meeker, wrote to the governor proposing legislation to help sheriffs defend their jails against mobs. Cummins did not publicly mention the Charles City lynching again, and he was silent on the issue in his inaugural address of January 14, when he outlined a series of penal reforms. Moreover, Cummins's proposed reforms of the justice system - indeterminate prison sentences

39. Ibid., 15, 18, 29 January, 5 February 1907; Des Moines Register and Leader, 16 January 1907. 
with a board of parole to administer them, the separation of first offenders from hardened criminals in the state prison system, and a separate institution for female offenders - offered little that spoke directly to the concerns of the Charles City lynchers. ${ }^{40}$

Governor Cummins's legal reforms, and his emphasis on the right to a fair trial in the Busse case, illustrated the gap between his view of the criminal justice system and that of the apologists for the Charles City lynching. Cummins desired an amelioration of abuses in prison conditions and sentencing in order to reform the criminal. Defenders of the Charles City lynching, on the other hand, sought effective and efficient means to protect the public from dangerous criminals. Both sought to protect the public interest from abuses, but their conceptions of that public interest diverged. For Cummins, the public interest rested in the guarantee of due process and the reeducation of the criminal for return to a productive role in society; for defenders of the Charles City mob, it resided in the harsh application of the law as a deterrent to prospective criminals. ${ }^{41}$

Several prominent residents of Charles City wrote directly to Governor Cummins following the lynching. They defended the mob killing and stressed that the hanging enjoyed the support of the great majority of town residents. They also criticized Cummins's role in the Busse affair, and asked him not to aid the attempt to prosecute Cullen's murderers. G. H. Fawcett, an insurance man and a notary public, bluntly told the governor that he should take part of the responsibility for the lynching.

I doubt not that if Busse had been hung, this crime would not have been committed, as Cullen read closely the proceedings in the matter, and when Busse's sentence was changed to life imprisonment, he says, "this man had ought to be hung, but if he cannot be hung, no man can be hung in Iowa."

40. Sayre, "Albert B. Cummins"; Waterloo Times-Tribune, 10 January 1907; Meeker to Cummins, 30 January 1907, Albert Baird Cummins Collection, Correspondence File, State Historical Society of Iowa, Des Moines; Des Moines Register and Leader, 11, 13 January 1907.

41. See Sayre, "Albert B. Cummins"; Bray, "The Cummins Leadership"; McDaniel, "Smith Wildman Brookhart," 50-51; Sage, History of Iowa, 216-48. 
... I do not believe that there is one out of a hundred that feels that Cullen did not get his just deserts, or partially so at least, and to be frank with you Mr. Cummins, there is not a very kindly feeling toward you at the present time in our quiet little town.

Fawcett added that no jury in Floyd County would convict anyone who took part in the hanging, nor would the county jail be strong enough to hold anyone convicted of taking part in the hanging. ${ }^{42}$

Fawcett's defense of Charles City and his criticism of Cummins was echoed by $W$. H. Williams, who addressed the governor on Hart-Parr Co. stationery.

I want to say to you, in all seriousness, that if Busse had been hanged, as he should have been, the recent lynching in Charles City would never have occurred. This community is free from any rough or hoodlum element, and is certainly as orderly and law abiding as any I have ever seen. The cause for such an upheaval must therefore be deep seated.

It seems to be a fact that it is harder to hang a guilty man in Iowa than for a rich man to enter the Kingdom of Heaven. The reason for this is the failure of the courts and the executive to enforce the laws. They pay more attention to hair-splitting technicalities than the spirit of the law; and seem bent on defeating the ends of justice whenever possible. ...

This is the sentiment of $90 \%$ of our citizens; and as a citizen of lowa, I am ashamed to say there is cause for it. ${ }^{43}$

GOVERNOR CUMMINS and Iowa's criminal justice system were not the only targets of attack. Defenders of the Charles City lynching also linked the resort to mob action to broader social and economic changes that affected Iowa communities in the early twentieth century. Charles City's population had grown nearly 50 percent between 1890 and 1895. The city's growth stabilized for the next decade, then mushroomed 30

42. Fawcett to Cummins, 14 January 1907, Albert Baird Cummins Collection, Correspondence File, State Historical Society of Iowa, Des Moines.

43. Williams to Cummins, 19 January 1907, Albert Baird Cummins Collection, Correspondence File, State Historical Society of Iowa, Des Moines. 
percent between 1905 and 1910 to 5,892. An expansion of the city's manufacturing base facilitated the population growth, as Hart-Parr Company, the gasoline engine and tractor manufacturer (later a part of the Oliver Corporation), began operation in Charles City in 1900. At that time, the city already contained fledgling manufacturers of agricultural implements and furniture. ${ }^{44}$

Although their city's growth was not on the scale experienced elsewhere, Charles Citians felt keenly the loss of local autonomy and popular sovereignty caused by the changes in the nation's social and economic life. The loss of control was especially evident in the ownership and operation of the railroads that ran through Charles City and other Iowa towns. Charles City residents, like the majority of Iowans and other midwesterners who supported progressivism, were receptive to political rhetoric that pitted the people's interests against those of the railroad trusts. Newspaper writers in Charles City praised individual money-making and financial accumulation and glorified the values of the "business class." $\mathrm{H}$. Durkee, for example, extolled the effect of Cullen's lynching on town property values. Yet these same Charles Citians feared the excessive profit-taking, the monopoly exercised by powerful corporations, and the erosion of societal morality that resulted, in their view, from an addiction to money. ${ }^{45}$

W. H. Leonard, a Charles City newspaper columnist, made the explicit connection between corporatization, changes in the social fabric, and the recourse to vigilantism.

Are we not, as a nation, running money mad to the neglect of those better qualities so essential to the perpetuity of our institutions, to the peace and well-being of our families, and to our individual salvation? ... The strong are oppressing the weak in government, in society, in business, and in some respects even in the house of God - the church. Conscience has become dulled

44. Iowa Census for 1905, 681; Iowa Census for 1915, 594; Floyd County Centennial Centurama, 1854-1958 (Charles City, 1954), 23-25.

45. Floyd County Advocate, 22 January, 8 February 1907. See also Robert Wiebe, The Search for Order, 1877-1920 (New York, 1967); and Olivier Zunz, Making America Corporate, 1870-1920 (Chicago, 1990). 
by the eroding influences of show, graft, and deception till law is losing the respect of the masses who have been led to believe in its efficacy only when applied to the weak. . .

It would almost seem that laws are enacted merely to satiate the spsmoadic [sic] demands of the public, but with little thought by the enactors that the measures will ever be permitted to fulfill the purpose intended.... That fault is an incubus to the enforcement of good laws which otherwise would remove the cause of mob violence, as well as curb the onslaught of monopolistic institutions against their weaker brethren.

In support of the foregoing facts, attention is called to the past dying wails of hundreds of business institutions that were being driven to the wall by such grasping combinations as the Standard Oil Trust, and the Sugar, Tobacco and Coal Trusts, to say nothing of the questionable acts of the great railways....

The enforcement of the law has been growing more expensive from year to year through an array of pernicious technicalities. ... The transgressor with means is buoyed up by technicalities and appeals till his outraged neighbors are finally compelled to throw up their hands, lest the expense of the trial deplete the funds of the county. Do you wonder, then, that a wronged community occasionally takes the law into its own hands? ${ }^{46}$

Charles Citians, and their defenders throughout the state, sought a more efficient, accessible government. They wanted a political process and a criminal justice system less beholden to privileged economic interests and more responsive to the public at large. Not opposed in principle to capitalism or money-making, they did fear the domination of their economic and social life by big business interests and wealthy individuals.

THE CHARLES CITY LYNCHING OF 1907 demonstrated the persistence of the vigilante tradition into the Progressive Era in Iowa. Charles Citians did not regard their resort to vigilantism as an anachronism, however, but rather as an effective way to remedy problems confronting their community in the early twentieth century. James Cullen's lynching was in fact murder, but for most Charles City residents lynching seemed akin to 
other progressive reforms - a "cheap [and] scientific" antidote (to paraphrase H. Durkee) for a pressing social problem. ${ }^{47}$

No Iowa mob has secured the death of a victim since January 9, 1907. Yet the American tradition of vigilantism survives. ${ }^{48}$ It is articulated whenever a community responds to serious violations of social norms by voicing - however tentatively - the option of taking the matter into its own hands. A sophisticated criminal justice apparatus and powerful cultural constraints now prevent Iowa communities from hanging their victims from tree limbs and bridges. Yet the notion, if not the physical realization, persists.

47. Ibid., 8 February 1907. For an interpretation stressing the communal basis and the progressive nature of the 1920s Ku Klux Klan in Indiana, see Leonard Moore, Citizen Klansmen: The Ku Klux Klan in Indiana, 1921-1928 (Chapel Hill, NC, 1991). Moore contends that the Klan sought to assert communal control over law enforcement in Indiana.

48. Perhaps the most prominent incident was the aborted lynching of a judge by frustrated farmers in Plymouth County in 1933. See Rodney D. Karr, "Farmer Rebels in Plymouth County, Iowa, 1932-1933," Annals of Iowa 47 (1985), 637-45. A mob in Skidmore, Missouri, no more than thirty miles from the Iowa border, lynched a town bully, Ken Rex McElroy, on July 10, 1981. Carl Navarre, "High Noon in Skidmore," Playboy (July 1982), 111, 144, 154, 156, 194-209; Harry N. MacLean, In Broad Daylight: A Murder in Skidmore, Missouri (New York, 1990). For the persistence of the vigilante ideology in Iowa in a more genteel version, see Douglas Wertsch, "Wallaces' Farmer's Crusade against Rural Crime in the 1920s," Annals of Iowa 50 (1990), 375-88. 
Copyright of Annals of Iowa is the property of State of Iowa, by \& through the State Historical Society of Iowa and its content may not be copied or emailed to multiple sites or posted to a listserv without the copyright holder's express written permission. However, users may print, download, or email articles for individual use. 